\title{
CORPORATE COMMUNICATION PT. XL AXIATA Tbk. MERESPON MASA KRISIS PANDEMI VIRUS COVID-19
}

\author{
Mokhammad Naigam Mahriva
}

\author{
Universitas Paramadina, Jakarta, Indonesia. \\ saya@naigam.com
}

\begin{abstract}
In a crisis situation the company or organization must take precautions as well as problem solving so that it is able to deal with the crisis. This also applies to PT. XL Axiata Tbk. telecommunications company in Indonesia which is facing a crisis period of corona covid-19 virus. This study aims to determine how corporate communication PT. XL Axiata Tbk. respond to the co-19 virus pandemic crisis period if it lasts a long time. The methodology in this research uses the concept of crisis and public relations crisis, with a qualitative approach, the paradigm used constructivism and data collection using in-depth interviews, literature study and documentation. As a telecommunications company, in this case the group head of corporate communication PT. XL Axiata Tbk. successfully responded to the crisis period of the covid-19 pandemic virus with four stages carried out in accordance with the problems encountered through the Emergency Response Team (ERT). The results showed that corporate communication had formed an Emergency Response Team (ERT before the crisis, this division was trained to respond, anticipate and deal with and deal with all crises appropriately and quickly the crisis of the telecommunications company PT XL Axiata Tbk.
\end{abstract}

Keywords: corporate communication, emergency response team, xl axiata, virus covid-19

\begin{abstract}
Abstrak
Dalam situasi krisis perusahaan atau organisasi harus melakukan tindakan pencegahan sekaligus pemecahan masalah sehingga mampu menghadapi krisis tersebut. Hal ini juga berlaku bagi PT. XLAxiata Tbk. perusahaan telekomunikasi di Indonesia yang sedang mengahadapi masa krisis virus corona covid-19. Penelitian ini bertujuan untuk mengetahui bagaimana corporate communication PT. XL Axiata Tbk. merespon masa krisis pandemi virus covid-19 apabila berlangsung lama. Metodologi dalam penelitian ini menggunakan konsep krisis dan krisis public relations, dengan pendekatan kualitatif, paradigma yang digunakan konstruktivisme serta pengumpulan data menggunakan wawancara mendalam, studi kepustakaan dan dokumentasi. Sebagai perusahaan telekomunikasi dalam hal ini grup head corporate communication PT. XL Axiata Tbk. berhasil merespon masa krisis pandemi virus covid-19 dengan empat tahapan yang dilakukan sesuai dengan masalah yang dihadapi melalui Emergency Response Team (ERT). Hasil penelitian menunjukkan bahwa corporate communication (komunikasi korporasi) sudah membentuk Emergency Response Team (ERT sebelum ada krisis, divisi ini sudah dilatih untuk merespon, mengantisipai dan menghadapi serta mengtasi segala krisis dengan tepat dan cepat krisis perusahaan telekomunikasi PT. XL Axiata Tbk.
\end{abstract}

Kata Kunci: komunikasi korporasi, tim respon darurat, xl axiata, virus covid-19

\section{PENDAHULUAN}

Perusahaan atau organisasi dimanapun berada pasti pernah mengalami isu atau masalah dalam menjalankan usahanya. Terlepas dari besarkecilnya masalah yang dialami perusahaan atau organisasi apabila tidak diantisipasi, maka perlahan akan berdampak buruk bahkan tidak menutup kemungkinan berlanjut menjadi krisis. Krisis tersebut bisa dalam wujud yang berbeda jenisya seperi bencana alam, bencana non alam, krisis keuangan dan krisis komunikasi.

Pada akhir tahun 2019 juga terjadi krisis 
dalam dunia asuransi di Indonesia. Peristiwa ini mengejutkan karena menyangkut berbagai pihak termasuk petinggi dan Badan usaha Milik Negara (BUMN).PT Asuransi Jiwasraya dililit utang belasan triliun rupiah karena perusahaan gagal bayar polis nasabah. Kasus ini kini tengah diselesaikan, termasuk memproses ke jalur hukum.Menteri Keuangan Sri Mulyani mengakui bahwa kasus BUMN asuransi ini sangat serius. Sebab potensi kerugian negara mencapai Rp 13,7 triliun. Kumparan. (2019, Desember 21).

Wuling Motors mendukung kebijakan pemerintah dalam mengurangi penyebaran Covid-19 dengan mulai menutup pabrik produksi mobilnya di Cikarang, Jawa Barat mulai 6 hingga 19 April 2020. Penutupan pabrik sementara itu dilakukan Wuling untuk melindungi karyawan dari infeksi virus mematikan tersebut. Penghentian sementara kegiatan produksi sebenarnya tidak hanya dilakukan oleh Wuling. Sebelumnya Suzuki juga memilih langkah yang sama dengan rencana menutup pabrik selama 2 minggu, mulai dari 13 April 2020 sampai 24 April 2020 di ketiga lokasi pabrik Suzuki, yaitu di Cakung, Tambun, dan Cikarang.suara.com. (2020, April, 6).

Dalam konteks Indonesia beberapa peristiwa tersebut terlihat karena akibat korupsi dan bencana non alam yang berdampak pada sosial ekonomi negara. Dalam kondisi imi manajemen krisis merupakan strategi yang sangat dibutuhkan oleh setiap organisasi atau perusahaan yang terkena dampak dari kejadian krisis. Krisis bisa hadir dalam berbagai wujud salah satunya seperti yang sedang terjadi saat ini, yaitu wabah virus Corona Covid-19. Pandemi ini telah memaksa banyak negara melakukan lockdown atau pembatasan mobilitas warganya sehingga berdampak pada aktivitas perekonomian negara tersebut.

Dampak yang ditimbulkan terjadi pada banyak perusahaan yang bergerak dibidang jasa dan pelayanan serta produk. Maka perusahaan perlu melakukan berbagai upaya untuk merespon dan mengantisipasi sekaligus mengatasi hal tersebut selama pandemik virus corona Covid-19 masih terjadi tak terkecuali di Indonesia. Banyak perusahaan atau organisasi harus mencari strategi untuk mengatasi masalah ini karena sifatnya yang lama dan melanda negara dan masyarakat di belahan bumi saat ini. Kejadian krisis, apapun bentuknya, bisa berpotensi mengancam keberhasilan bisnis dan tentunya berdampak negatif pada keuangannya. Oleh karena itu, dibutuhkan penanganan yang tepat agar bisnis tetap bisa bertahan di tengah krisis.

Pandemik virus corona Covid-19 ini berimbas pada perusahaan telekomunikasi di Indonesia. PT. XL Axiata Tbk. mengaku ikut terdampak oleh pandemi virus corona di Indonesia. Namun, perusahaan ini tetap berniat melanjutkan ekspansinya di tahun ini. Kebijakan untuk memberlakukan belajar (learning from home) dan bekerja dari rumah (work from home) praktis menjadikan operator telekomunikasi sebagai penyedia internet menjadi tulang punggung bagi kegiatan masyarakat selama pandemi Covid-19 ini. Sehingga perusahaan harus mempersiapkan strategi bisnis yang memperkuat posisi sehingga mampu merespon dan mengantasipasi krisis apabila berkepanjangan.

Dalam situasi krisis akibat pandemi virus corona covid-19 saat ini, sektor telekomunikasi dianggap sebagai bisnis yang paling kebal. PT. XL Axiata Tbk. (EXCL) mengaku telah merasakan sejumlah kendala akibat pandemi. Seluruh industri pasti terdampak oleh Covid-19, tak terkecuali bisnis telekomunikasi. Sejumlah tekanan akan dialami oleh bisnis yang dalam telekomunikasi salah satunya harga saham perusahaan telah jauh tertekan. Tetapi yang menjadi dampak saat ini operasional yang sangat terasa oleh krisis ini karena PSBB akibatnya ruang gerak yang terbatas. Wahyuningsih, T. (Maret, 2020). Wawancara Pribadi.

Implementasi bisnis dari rencana kerja 
perseroan juga mesti diubah dan menyesuaikan dengan keadaan yang ada, seperti alokasi investasi untuk memenuhi kebutuhan trafik pengguna yang meningkat, termasuk menambah coverage dan kapasitas bandwith. Selain itu, dampak dari pandemi juga dirasakan oleh mitra bisnis PT. XL Axiata Tbk. yang mulai kesulitan menjalankan bisnisnya sehingga menyebabkan supply chain perseroan terganggu. PT. XL Axiata Tbk. akan berpotensi merugi karena daya beli masyarakat sudah cenderung turun. Meskipun hingga akhir Maret 2020 atau akhir kuartal pertama tahun ini belum ada dampak signifikan.

Krisis adalah suatu kejadian yang ta terduga dan bisa merugikan reputasi, citra, dan kredibilitas perusahaan, organisasi atau individu (Cangara, 2017:202).Artinya krisis tidak hanya terjadi pada perusahaan atau organisasi karena mengalami penuruan pelanggan, melainkan krisis bisa terjadi pada semua bidang usaha, organisasi social politik, dan juga bidang pelayanan publik. Cara penyelesaiannya hampir sama tetapi berbeda pendekatan karena konteks yang berbeda.

Ketikakrisis makaperusahaanatau organisasi perlu alat untuk menangani krisis tersebut. Menurut Kriayantono (2012) manajemen krisis merupakan sebuah proses yang menggunakan aktivitas public relations untuk mengatasi akibat negatif, manajemen krisis merupakan tanggung jawab seorang public relations. Hal ini sejalan dengan disimpulkan bahwa seharusnya public relations diberikan posisi yang memungkinkan berperan dalam proses merumuskan dan mengimplementasikan strategi menangani krisis (Safitri dan Aslati, 2019).

Dalam literatur lain (Ardianto, 2013) mengatakan bahwa krisis adalah situasisituasi yang ditandai dengan keterkejutan dan mengancam nilai-nilai penting, serta mengharuskan membuat keputusan dalam waktu singkat. Krisis juga dapat diartikan sebagai sebuah situasi atau kejadian besar dengan dampak negatif yang secara potensial mempengaruhi sebuah organisasi atau industri, termasuk publiknya, produknya, jasanya atau nama baik (dalam Sa'diyah, 2017:134-147).

Dalam perusahaan public relations memiliki beberapa peranan penting, public relations dianggap sebagai mata dan telinga dari perusahaan.Salah satunya adalah peran sebagai pemecah masalah (problem solver) yaitu dalam menangani persoalan dan krisis yang terjadi pada perusahaan.Manajemen krisis (crisis management) merupakan keahlian yang harus dimiliki oleh seorang public relations.Tujuan dari manajemen krisis adalah untuk menghentikan dampak negatif dari suatu peristiwa melalui upaya persiapan dan penerapan beberapa strategi dan taktik (Kriyantono, 2015:180).

Public Relations Sebagai wakil dari manajemen perusahaan, dengan tugas utama menghubungkan pihak yang berkepentingan, baik di dalam maupun di luar perusahaan, public relation harus menguasai etikaetika, baik yang umum maupun tidak umum, berupa a) komunikator yang baik (good communicator), baik untuk publik eksternal maupun internal; b) menempatkan faktor kejujuran (integrity) sebagai landasan utamanya; c) meningkatkan sense of belonging dan sense of wanted pada karyawan; d) menjaga etika dalam komunikasi keseharian dan berinteraksi; e) menyampaikan informasi-informasi penting secara bertanggung jawab, kepada anggota dan kelompok yang berkepentingan; f) menghormati prinsip-prinsip rasa hormat terhadap nilai-nilai kemanusiaan; g) menguasai teknik dan cara penanggulangan kasuskasus, sehingga dapat memberikan keputusan, dan pertimbangan secara bijaksana; h) mengenal batasbatas yang berdasarkan pada moralitas dalam profesinya; i) penuh dedikasi dalam profesinya; dan j) menaati kode etik humas. Berkaitan dengan peran sentralnya yang kuat, yaitu sebagai penghubung (di antara perusahaan dengan publik), back-up management dan membentuk corporate image yang baik sehingga seluruh ucapan, sikap dan tindakannya akan menyangkut nilai diri dan citra perusahannya, 
kualifikasi personal public relation sangat penting. Kualifikasi umum personil public relation adalah a) syarat kepribadian berupa aktif dan kreatif, berpengalaman, sopan, ramah dan simpatik, penuh pengertian, berwawasan luas, berkepribadian kuat dan memiliki referensi yang baik; b) syarat fisik berupa kesehatan yang baik, mudah tersenyum, lancar berbicara, dan suara nyaring/merdu; c) syarat mental berupa bersimpati, teliti dan waspada, bertanggungjawab, serta optimis, jujur dan percaya diri; d) syarat karakter berupa dapat dipercaya, beritikad baik, setia, rajin, teliti, tepat waktu, beritikad baik serta bersikap dan berperilaku terpuji; dan e) syarat sosial berupa pandai bergaul, toleran dan bersedia untuk bekerjasama (Natawilaga, 2018:64-71).

Hal ini sejalan dengan pernyataan Timothy Coombs (2012) mendefinisikan krisis sebagai persepsi akan kejadian yang tidak dapat diprediksi yang mengancam harapan pemangku kepentingan yang secara serius dapat mempengaruhi kinerja sebuah organisasi dan menghasilkan output negatif. Sedangkan komunikasi krisis adalah pengumpulan, pemrosesan, dan penyebaran informasi yang diperlukan untuk menangani situasi krisis. Sebuah fitur penting dari komunikasi krisis adalah pengelolaan komunikasi organisasi yang kompleks (dalam Akhyar dan Pratiwi, 2019:35-52)

Krisis Public Relations sering juga disebut krisis komunikasi, terjadi karena pemberitaan negatif yang kemudian berimbas buruk pada bisnis perusahaan atau jalannya organisasi. Pemberitaan media atau isu yang beredar bisa jadi benar atau mungkin saja tidak, tetapi berpotensi mempengaruhi citra atau reputasi dari perusahaan atau organisasi. Krisis Public Relations adalah suatu peristiwa yang dapat membahayakan image perusahaan atau organisasi, reputasi maupun stabilitas keuangan.Semakin besar krisisnya, semakin buruk dampaknya bagi perusahaan atau organisasi (Nova, 2011:153).

Jika dipandang dari kacamata bisnis, suatu krisis akan menimbulkan hal-hal berikut (Nova, 2011:70): 1) Intensitas permasalahan akan bertambah; 2) Masalah akan menjadi Sorotan Publik baik melalui media massa atau informasi dari mulut ke mulut; 3) Masalah akan mengganggu kelancaran bisnis seharihari; 4) Masalah mengganggu nama baik perusahaan; 5) Masalah dapat merusak sistem kerja dan mengguncang perusahaan secara keseluruhan; 6) Masalah yang dihadapi selain membuat perusahaan menjadi panik, tidak jarang juga membuat masyarakat menjadi panik; 7) Masalah akan membuat Pemerintah ikut melakukan intervensi.

Krisis dapat terjadi secara alamiah, tidak terprediksi, dan tidak selalu merupakan hal yang buruk.Dalam menghadapi krisis, optimisme untuk menyusun langkah-langkah agar dapat keluar dari krisis merupakan modal utama. Pemberitaan media massa yang menggiring kearah negatif harus diseimbangkan dengan cara mempengaruhi pola pikir masyarakat bahwa krisis tidak selalu memiliki sisi negatif.

Beberapa keadaan yang dapat dikategorikan sebagai krisis bagi suatu perusahaan misalnya, kegagalan produksi, hostile takeover, krisis keuangan global, tuntutan pengadilan, bencana alam, kerusuhan, perang, pergantian pemimpin, unjuk rasa pekerja, dan lain-lain. Krisis juga dapat dikategorikan berdasarkan (Nova, 2011:70-71): 1) Krisis level 1: dampak dari krisis ini mengakibatkan tercemarnya nama organisasi serta adanya hambatan dalam mewujudkan misi; 2) Krisis level 2: krisis ini berdampak pada cedera fisik, kemungkinan korban jiwa, rusaknya property, hancurnya reputasi perusahaan atau kombinasinya; 3) Krisis level 3: krisis ini mengakibatkan adanya korban jiwa, kerusakan properti yang serius serta kemungkinan kebangkrutan.

Definisi manajemen krisis tersebut merupakan salah satu dari semakin banyak definisi manajemen krisis. Dari definisi itu, diambil beberapa poin dimana (1) semakin hari praktik manajemen krisis semakin dibutuhkan, (2) manajemen krisis merupakan 
bagian kegiatan PR, dan (3) manajemen krisis merupakan sebuah perencanaan terperinci dalam menghadapi krisis yang menimpa sebuah perusahaan. Perlunya dilaksanakan manajemen krisis adalah (1) untuk menyiapkan perlindungan yang lebih baik melawan dampak dari krisis, (2) untuk dapat memberikan respon yang efektif terhadap suatu krisis yang sedang terjadi, dan (3) untuk memberikan rencana-rencana dan sumber-sumber untuk penyembuhan dan rehabilitasi setelah krisis terjadi. Besarnya pengaruh pelaksanaan manajemen krisis inilah yang menjadikan PR dituntut untuk menjalankan manajemen krisis secara tepat, cepat, dan akurat. Sebuah tuntutan agar dilaksanakannya manajemen krisis yang secara tepat, cepat, dan akurat, dikarenakan manajemen efektif untuk menyelesaikan krisis, juga akan berpengaruh pada corporate image dihadapan publiknya, dan secara otomatis juga akan berdampak pada eksistensi perusahaan di masa yang akan datang (Cutlip, 2000:326) dalam Suryani, I. \& Sagiyanto, A. (2018)

Untuk menyelaraskan kerja penanganan krisis PR dengan langkah-langkah strategis manajemen, PR bisa melakukan 3 hal berkaitan dengan pemberitaan media massa untuk meyakinkan fungsinya kepada manajemen (Wasesa dan Macnamara, 2010:92-93): 1) Mengidentifikasi isu-isu penyebab krisis: buat perbandingan antara isu yang muncul dan situasi yang terjadi. Seringkali bobot isu jauh lebih besar ketimbang krisis itu sendiri. Jadikan kesenjangan antara isu yang muncul dalam media dan situasi atau fakta yang sebenarnya ada untuk meyakinkan manajemen bahwa ada yang perlu dijelaskan kepada publik mengenai isu yang terjadi; 2) Memetakan Kebutuhan Wartawan Saat krisis: berikan gambaran kepada manajemen bahwa dalam situasi krisis, pihak pimpinan puncak manajemen akan lebih diharapkan oleh wartawan ketimbang PR Officer. Dalam situasi krisis, peran PR Officer harus lebih banyak di belakang layar. Sementara peran kuncinya ada di pihak manajemen; 3) Siapkan talking points untuk manajeme:
Sesaat setelah manajemen berhadapan dengan wartawan atau media, pastikan dan yakinkan bahwa mereka telah memberikan informasi yang benar. Untuk setiap media yang memuat hasil interviu dalam pemberitaan, paparkan kembali jalur informasi yang terbentuk dari hasil wawancara tersebut.

Maka dari kasus krisis tindakan pengelolaan krisis yang bisa dilakukan oleh public relations yaitu manajemen krisis.Manajemen krisis sebagai upaya untuk mencegah atau mengurangi hasil negatif dari krisis untuk melindungi organisasi serta para stakeholder, membagi manajemen krisis menjadi tiga bagian yaitu pre-crisis, crisis dan post-crisis, berikut ini penjelasan dari masing-masing tahapan (Coombs \& Holladay, 2010). Precrisis merupakan tahap sebelum terjadi krisis, tindakan yang dilakukan yaitu mengumpulkan seluruh informasi tentang resiko krisis, menentukan respon yang dilakukan saat krisis dan mempersiapkan sosok terpercaya, yang akan memberikan informasi pada publik. Selanjutnya yaitu crisis, pada tahap organisasi sedang berada dalam situasi krisis dan harus memberikan respons yang tepat, sehingga bisa tertangani dengan baik.Dalam Yulianti, W. \& Boer R.F. (2020).

Dari penjelasan latarbelakang, maka masalah yang dihadapi oleh PT. XL Axiata Tbk akibat situasi ini operasional perseroan turut terdampak, dari mulai beban biaya pajak yang masih jalan karena banyak penyesuaian operasional serta pelayanan kepada masyarakat yang terganjal social distancing. Meskipun perusahaan sudah dapat surat rekomendasi dari berbagai institusi, tetap ada sejumlah lokasi yang masyarakatnya menolak karyawan untuk melakukan aktivitas dan pelayanan, sehingga tidak bisa memperbaiki atau memasang perangkat yang baru.

Maka penelitian ini difokuskan pada tindakan yang dilakukan oleh coporate communication PT. XLAxiata Tbk. dalam masa krisis melalui ERT (Emergencing Response Team). Bagaiamana perusahaan merespon 
dan mengantisipasi serta menghadapi krisis virus corona Covid-19 ini. Sehingga penelitian diarahkan pada tahapan kerja yang dilakukan perusahaan dalam merespon krisis ini. Maka tujuan penelitian ini untuk mengetahui bagaimana corporate communication PT. XL Axiata Tbk. melalui ERT merespon pandemi virus corona Covid-19 sehingga mampu bertahan dan tidak mengalami krisis sebagai perusahaan telekomunikasi di Indonesia.

Untuk memperkuat penelitian tentang manajemen krisis dan bagaimana perusahaan menghadapinya situasi krisis tesebut, maka penelitian sejenis yang relevan pertama yang dilakukan (Kustiawati, Setiadarma \& Priliantini, 2019) pada perusahaan jasa makanan yaitu Pizza Hut ketika terkena isu bahan makanan menggunakan pengawet yang dimuat dalam laporan khusus majalah Tempo dan BBC. Peneliti menyebutkan bahwa strategi penanganan isu tidak dapat digeneralisasi. Strategi yang digunakan untuk suatu isu belum tentu efektif untuk menangani isu lainnya, begitu pula sebaliknya. Meskipun demikian, setidaknya ada tahapan baku yang harus dijalankan oleh seorang public relations dalam mengelola sebuah isu. Sebelum terjadinya krisis pada perusahaan maka isu yang terjadi harus diantisipasi dengan menggunakan manajemen isu dan manajemen isu meliputi 5 tahap yang saling berkesinambungan.

Penelitian kedua yang relevan, dilakukan oleh (Akhyar dan Pratiwi, 2019) tentang media sosial dan manajemen komunikasi krisis pada perusahaan telekomunikasi. Penelitian ini menyimpulkan bahwa ada empatcara yang dapat dilakukan dalam menghadapi situasi krisis. Simpulan yang bisa diambil dari penelitian ini ada tiga hal yaitu pertama, penyelesaian krisis di media sosial bisa dianalisis dari siapa stakeholder (pemangku kepentingan) yang terlibat dalam krisis tersebut. Kedua, krisis di media sosial harus segera ditangani karena potensi viral yang besar yang bisa berakibat fatal karena mengancam reputasi baik organisasi. Ketiga, walaupun krisis terjadi viral di media sosial, tetapi respons krisis bisa dilakukan tidak hanya secara online tetapi juga offline. Keempat, dalam krisis berskala besar dengan melibatkan isu sosial yang kuat, hadirnya CEO atau pimpinan tertinggi perusahaan dalam strategi merespons dan menjelaskan langsung ke publik membawa dampak signifikan untuk crisis recovery (memulihkan krisis).

Penelitian ketiga, tentang krisis yang terjadi pada organisasi pemerintahan Kementerian Pertanian dengan topik dugaan penimbunan beras di daerah Bekasi juga diteliti dengan menggunakan teori Situational Crisis Communication Theory (SCCT). Teori ini dipilih berdasarkan pertimbangan bahwa Kementerian Pertanian cenderung melihat persepsi publik terhadap satu isu atau kasus sebelum kemudian mengambil tindakan yang dianggap sesuai. Menurut teori ini, pada dasarnya publik mempunyai atribusi tertentu tentang krisis, atribusi tersebut akan menentukan reputasi organisasi. Atribusi pada dasarnya adalah persepsi public terhadap krisis. Kata-kata yang ada pada manajemen akan memengaruhi bagaimana publik mempersepsi organisasi dan krisis. Penelitian ini diharapkan mampu memberikan gambaran bagaimana komunikasi krisis yang dilakukan oleh Kementerian Pertanian serta untuk menambah kajian tentang komunikasi krisis pemerintah di Indonesia (Putri, Sutopo \& Rahmanto, 2019).

Perbedaan penelitian ini dengan penelitian sebelumnya terletak pada pendekatan dan konteks karena waktu yang berbeda. Krisis saat ini masih berlangsung ketika penelitian ini dilaksanakan itu sebabnya konteksnya juga berbeda. Penelitian-penelitian sebelumnya terkait tentang isu makanan, dugaan korupsi perusahaan telekomunikasi dan kebijakan pemerintah dalam hal ini penimbunan beras. Penelitian ini terkait bencana tentang Virus Covid-19 yaitu pandemi atau wabah penyakit yang berhubungan dengan kesehatan dan dikategorikan bencana non alam. Dan situasi krisis ini baru pertama kali terjadi sehingga menarik diteliti karena masih berlangsung 
sampai saat ini.

\section{METODOLOGI}

Penelitian ini menggunakan paradigma konstruktivisme. Alasan peneliti menggunakan paradigma ini karena berorientasi untuk menemukan pengertian atau pemaknaan atas sebuah hal serta memberikan penjelasannya menggunakan nalar sendiri, dalam hal ini adalah manajemen krisis PT. XL Axiata Tbk. dalam menghadapi krisis. Bagaimana krisis tersebut dipahami dan dikonstruksi oleh perusahaan.Aliran konstruktivisme menyatakan bahwa realitas itu ada dalam beragam bentuk konstruksi mental yang didasarkan pada pengalaman sosial, bersifat lokal dan spesifik, serta tergantung pada pihak yang melakukannya. Oleh karena itu, sebuah realitas yang diamati oleh peneliti tidak bisa digeneralisasikan kepada semua orang.Dalam paradigma, hubungan antara pengamat dan objek merupakan satu kesatuan, subjektif dan merupakan hasil perpaduan interaksi antar keduanya (Moleong, 2010:70). Peneliti mendasari penelitian menggunakan paradigma ini dengan tujuan untuk mengungkap kegiatan secara komperhensif dan mendalam. Pendekatan penelitian menggunakan penelitian kualitatif. Penelitian kualitatif adalah metode penelitian yang digunakan untuk meneliti pada kondisi obyek yang alamiah, dimana peneliti adalah sebagai instrument kunci, teknik pengumpulan data dilakukan secara triangulasi (gabungan), analisis data bersifat induktif, dan hasil penelitian kualitatif lebih menekankan makna daripada generalisasi (Sugiyono, 2014:1).

Dalam penelitian ini peneliti memakai pendekatan deskriptif kualitatif yang bertujuan untuk mengenal, mendapatkan, serta memberikan gambaran atau paradigma mengenai suatu gejala. Penelitian ini berusaha untuk memperlihatkan gambaran tentang manajemen krisis XL Axiata menghadapi situasi krisis semasa pandemi virus covid-19 yang diharapkan mampu menghasilkan suatu uraian, mendalam tentang ucapan, tulisan, dan tingkah laku yang dapat diamati dari suatu individu, kelompok, masyarakat, organisasi tertentu dalam suatu konteks setting tertentu yang dikaji dari sudut pandang yang utuh dan komperhensif.

Metode penelitian yang digunakan dalam penelitian ini adalah studi kasus. Sebuah studi kasus memberikan deskripsi tentang individu. Individu ini biasanya adalah orang, tapi biasa juga sebuah tempat seperti perusahaan, sekolah, dan lingkungan sekitar. Menurut Yin (2017:8) studi kasus merupakan penyelidikan yang bersifat empiris yang menginvestigasi sebuah fenomena dalam kehidupan nyata. Metode yang digunakan dalam penelitian ini studi kasus, karena peneliti berusaha melakukan eksplorasi mendalam dan memberikan penjelasan yang komperhensif mengenai suatu objek, untuk mengetahui bagaimana corporate communication PT. XL Axiata Tbk. melalaui ERT dalam mengantisipasi situasi krisis semasa pandemi virus covid- 19 .

Dalam penelitian ini peneliti menggunakan Triangulasi Sumber dalam pengujian keabsahan data. Triangulasi sumber dilakukan dengan menguji kredibilitas data dilakukan dengan cara mengecek data yang telah diperoleh melalui beberapa sumber. Data yang diperoleh kemudian dideskripsikan dan dikategorisasikan sesuai dengan apa yang diperoleh dari berbagai sumber tersebut. Peneliti akan melakukan pemilahan data yang sama dan data yang bebeda untuk dianalisis lebih lanjut. Triangulasi dalam pengujian kredibilitas ini diartikan sebagai pengecekan data dari berbagai sumber dan berbagai cara. Rencana pemeriksaan keabsahan data yang digunakan dalam penelitian ini melalui triangulasi sumber. Hal itu dapat dicapai dengan: 1) Membandingkan data hasil pengamatan dengan data hasil wawancara yang dilakukan kepada narasumber pertama (pimpinan PT. XL Axiata Tbk.) Tri Wahyuningsih; 2) Membandingkan data hasil pengamatan atas narasumber dari pihak PT. XL Axiata Tbk. dengan narasumber kedua yaitu 
Andy Satrio Yudho dari Emergency Response Team (ERT) yang melakukan antisipasi krisis terhadap pemangku kepentingan dan publik. Dalam penelitian ini peneliti menggunakan triangulasi, yang berarti peneliti dapat me-rechek temuannya dengan jalan membandingkannya dengan berbagai sumber, metode atau teori.

\section{HASIL DAN PEMBAHASAN Hasil}

Banyak perusahaan atau organisasi berpikir bahwa krisis hanya akan menyerang perusahaan atau organisasi besar, padahal krisis dapat menyerang siapa saja, baik individu, perusahaan atau organisasi, kapan dan di mana saja. Krisis merupakan ujian bagi eksistensi pribadi, kelompok, dan perusahaan atau organisasi.Sehingga dibutuhkan kemampuan untuk menghadapi krisis dengan memahami prinsip-prinsip yang benar.

Karakteristik krisis pada umumnya adalah adanya ketidakstabilan tinggi yang berpotensi menimbulkan dampak negatif terhadap kelangsungan hidup perusahaan atau organisasi. Kata krisis berasal dari bahasa Yunani yang berarti "mengayak atau memisahkan". Oleh sebab itu, krisis dapat membedakan masa lalu dengan masa depan perusahaan atau organisasi, membedakan pemimpin yang efektif dan tidak serta merta mengubah perusahaan atau organisasi secara signifikan.

Upaya yang ditempuh PT. XL Axiata Tbk. berfokus pada peningkatan pelayanan seperti pengembangan kualitas jaringan secara end to end. Hal ini dilakukan dengan terus memperluas dan meningkatkan kapasitas jaringan layanan data khususnya untuk layanan $4 \mathrm{G}$ dan $3 \mathrm{G}$ termasuk fiberisasi di berbagai wilayah Indonesia, khususnya luar Jawa. Hal lain juga meningkatkan kenyamanan bagi pelanggan untuk mendapatkan informasi mengenai penawaran produk dan layanan termasuk kemudahan transaksi melalui berbagai saluran baik offline maupun online. Tindakan lain yang dilakukan pihak PT. XL Axiata Tbk. menyediakan berbagai pilihan layanan data yang sesuai dengan kebutuhan pelanggan (value for money), serta menyediakan berbagai paket smartphone yang dilengkapi fitur layanan data.

Langkah-langkah diatas adalah langkah khusus tekait kinerja komunikasi yang dalam lingkup Corporate Communication PT. XL Axiata Indonesia Tbk. melalui Emergency Response Team (ERT). Masa krisis ini dapat ditangani dengan baik kalau PR dalam hal ini Corporate Communication mampu membuat pemetaan atas apa yang diperbincangkan masyarakat terkait isu yang ditangani. Sehingga ketika krisis terjadi pada perusahaan, Emergency Response Team (ERT) sudah mempunyai bahan untuk disodorkan ke pihak manajemen kemudian disampaikan ke Publik.

Ada tahapan yang dilakukan oleh Corporate Communication PT. XL Axiata Tbk. melalui Emergency Response Team (ERT) dalam menghadapi krisis akibat pandemic virus corona Covid-19 di Indonesia. ERT terdiri dari beberapa divisi seperti marketing, human resources, internal relations, eksternal relations, finance controller, public relations, health safety environment.

Tim ini sudah ada sebelum pandemi ini muncul, bahkan ERT ini sudah dipersiapkan dan dilatih untuk menghadapi segala krisis. ERT sudah mulai bekerja dibulan februari, sudah mempersiapkan jika pandemi ini menghantui Indonesia. ERT ini yang bekerja untuk membuat analisis baik secara mikro dan makro dengan strategi untuk merespon, mengantisipasi dan menghadapinya. Hasil penelitian menunjukkan bahwa tahapan tersebut antara lain:

\section{Tahap Pembentukan Tim}

PT. XL Axiata Tbk. sudah menyiapkan langkah-langkah dan sudah memiliki team krisis atau disebutnya Emergency Response Team (ERT). Saat ini bisnis PT. XL Axiata belum terdampak krisis secara langsung, tetapi jika sudah berjalan 6 bulan kemungkinan 
akan terkena dampak dari krisis ini. Dampak operasional yang sangat terasa oleh krisis ini karena PSBB karena ruang gerak yang terbatas. Pada tahap ini ERT melakukan pemetaan atas isu-isu yang dihadapi terkait telekomunikasi di Indonesia. Hasil pemetaan berupa persaingan telekomunikasi, pergerakan saham, regulasi telekomunikasi dan protocol kesehatan. ERT membagi isu tersebut ke dalam beberapa kelompok, antara lain internal terkait sistem dan human resource, eksternal menyangkut industri berupa aturan dan kebijakan dari pemerintah serta dampak global yang ditimbulkan menyangkut kompetisi dan situasi terhadap industri telekomunikasi. Dari pemetaan ini akan memunculkan prioritas mana yang akan diselesaikan secepatnya.

\section{Tahap Analisis}

Saat ini memang perusahaan belum krisis, tetapi kalau sudah 6 bulan bisa saja mengalami krisis. Belum krisis karena bisnis masih berjalan walaupun WFH. Pada tahap ini, Corporate Communication XL Axiata membangun komunikasi dengan berbagai pemangku kepentingan untuk menyamakan persepsi atas situasi yangterjadi. ERT kemudian mengidentifikasi kemampuan sumber daya internal dan eksternal, lalu menganalisa segala kemungkinan dan pengaruh yang potensial terjadi. Untuk krisis akibat pandemi ini, team ERT sudah mulai bekerja dibulan februari, sudah mempersiapkan jika pandemi ini menghantui Indonesia. ERT ini membuat apps utk internal karyawan, latihan kerja WFH, monitoring karyawan dan internal komunikasi malah sampai dengan membuat buku panduan internal disebut buku putih. XL Axiata melakukan pemantauan (monitoring) media massa dan media sosial serta melakukan diskusi dengan kelompok-kelompok yang terkait dengan penanganan pandemi virus corona Covid-19 untuk mengetahui semua isu yang berkaitan dengan telekomunikasi.

\section{Tahap Perencanaan}

Setelah ERT membuat analisis mana yang harus segera diselesaikan, maka dilakukan tahap ketiga yaitu tahap perencanaan. Terkait dengan yang pandemi Covid-19, PT. XL Axiata Tbk. menyatakan telah menyiapkan berbagai langkah antisipasi untuk menghadapi pandemi tersebut untuk memastikan keberlangsungan layanan telekomunikasi bagi masyarakat di masa darurat saat ini. Sejak kebijakan bekerja dari rumah diterapkan pada 17 Maret 2020, operasional selama masa krisis pandemi virus corona Covid-19 dengan crash program. Pada tahap ini PT. XL Axiata Tbk. melakukan tahap perencanaan yaitu komitmen perusahaan, bahwa jika terjadi krisis, perusahaan akan menjaga transparansi dalam setiap tindakan yang dilakukan, tidak boleh ada hidden agenda kepada internal dan eksternal, mengadakan internal sharing informasi secara berkala dan memberikan informasi yang menenangkan stakeholders.

\section{Tahap Implementasi}

Implementasi bisnis dari rencana kerja perseroan juga mesti diubah dan menyesuaikan dengan keadaan yang ada, seperti alokasi investasi untuk memenuhi kebutuhan trafik pengguna yang meningkat, termasuk menambah coverage dan kapasitas bandwith. Sejak awal berjangkitnya Covid-19 di Indonesia, PT. XL Axiata Tbk. telah melaksanakan program yang bersifat sosial. Antara lain berupa peluncurkan program gratis akses data $2 \mathrm{~GB} /$ hari untuk mengakses aplikasi-aplikasi penunjang kerja dan belajar dari rumah, website kesehatan pemerintah, e-Learning, saluran daring universitas untuk membantu pelanggan tetap produktif. Selain itu PT. XL Axiata Tbk. telah menyerahkan donasi berupa tunai maupun non-tunai seperti alat pelindung diri (APD), layanan komunikasi gratis untuk petugas mitigasi Covid-19, serta memperkuat jaringan di area sekitar rumah sakit rujukan Covid-19. Total nilai bantuan yang telah diberikan baik 
tunai maupun non-tunai lebih dari Rp 100 miliar untuk semua program pencegahan Covid-19, termasuk memberikan gratis akses data yang disalurkan keberbagai instansi dan perseorangan.

\section{Pembahasan}

Bila dikaitkan dengan konsep manajemen krisis tentang tahapan dalam krisis, maka sedikit banyak ada kesamaan walaupun ada perbedaan penyebutan tahapan. Bila mengacu pada konsep manajemen krisis, tahapan yang dilakukan oleh Group Head Corporate Communication melalui Emergency Response Team (ERT) sejalan dengan yang disampaikan Nova (2011).

Peramalan Krisis (forcasting); manajemen krisis bertujuan untuk menekan faktorfaktor resiko dan faktor ketidakpastian seminimal mungkin. Setiap perusahaan menghadapi masa depan yang berubah dan tidak terduga (uncertainty condition). Dalam hal ini perusahaan dapat mengidentifikasi dan menganalisa peluang (opportunity) dan ancaman (threat) yang terjadi di dunia bisnis. Pada tahap ini pihak PT. XL Axiata Tbk. membemtuk tim dan melakukan analisis dengan melakukan pemetaan atas isu-isu yang dihadapi terkait telekomunikasi d Indonesia. Dari pemetaan ini akan memunculkan prioritas mana yang akan diselesaikan secepatnya, perusahaan sudah menyiapkan langkahlangkah XL Axiata memiliki team krisis atau disebutnya Emergency Response Team (ERT). Tim ini sudah ada sebelum Pandemi ini muncul, bahkan ERT ini sudah dipersiapkan dan dilatih untuk menghadapi segala krisis. ERT ini yang bekerja untuk membuat analisis baik secara mikro dan makro dengan strategi untuk menghadapinya. Kegiatan ini dilakukan sepenuhnya ERT yang berkordinasi dengan ERT Leader, dan disupport oleh Group Head Corporate Communication dan Group Head People Service, termasuk mengelola media social.Tim ini bertugas memantau secara berkala perkembangan telekomunikasi dengan berbagai kebijakan yang terkait.Tim ini melakukan pemantauan berita-berita, isu, competitor melalui pemantauan yang terusmenerus. Bahkan XL Axiata bekerjasana dengan tim gugus tugas dan lembaga lain untuk menyelaraskan kegiatan dan program yang terkait penanganan virus corona covid-19 ini. PT. XL Axiata Tbk. tidak mencari dan menganalisis setiap informasi, opini, atau bahkan isu yang menyangkut perusahaan. Melalui tahap ini pula XL Axiata dapat lebih cepat menentukan sikap dalam menyusun strategi untuk menghadapi isu yang ada.

Pencegahan Krisis (prevention); langkahlangkah pencegahan sebaiknya diterapkan pada situasi pra krisis. Untuk mencegah kemungkinan terjadinya krisis. Namun, jika krisis tidak dapat dicegah, manajemen harus mengupayakan agar krisis tidak menimbulkan kerugian yang lebih besar, Untuk itu, begitu terlihat tanda-tanda krisis, segera arahkan ke tahap penyelesaian. Pada tahap ini PT. XL Axiata Tbk. melakukan tahap perencanaan yaitu komitmen perusahaan, bahwa jika terjadi krisis, perusahaan akan menjaga transparansi dalam setiap tindakan yang dilakukan, tidak boleh ada hidden agenda kepada internal dan eksternal, mengadakan internal sharing informasi secara berkala dan memberikan informasi yang menenangkan stakeholders.

Intervensi Krisis (intervention); langkah intervensi dalam situasi krisis bertujuan untuk memgakhiri krisis.Pengendalian terhadap kerusakan (damage control) dilakukan pada tahap akut.Langkah-langkah pengendalian terhadap kerusakan diawali dengan identifikasi, isolasi (pengucilan), membatasi (limitation), menekan (reduction), dan diakhiri dengan pemulihan (recovery).Pada tahap ini pihak PT. XLAxiata Tbk, melakukan tahap implementasi. Langkah konkrit pada tahap ini yang dilakukan PT. XL Axiata Tbk. untuk mengantisipasi krisis secara internal yaitu komitmen dari management PT. XL Axiata Tbk. tidak akan ada pengurangan pegawai dalam krisis ini. Bisnis PT. XL Axiata Tbk. tetap berjalan 
karena dalam peraturan pemerintah, PT. XL Axiata Tbk. salah satu perusahaan yang boleh berjalan untuk operasionalnya.PT. XL Axiata Tbk. secara tegas melakukan isolasi dengan menetapkan WFH untuk smua karyawannya. Hal ini juga sebagai pembatasan dan menekan penyebaran virus di perusahaan.Intervensi secara langsung yaitu anggaran training bagi karyawan diperbolehkan untuk digunakan untuk membeli alat2 penunjang WFH sebab bagi beberapa orang karyawan WFH lebih produktif dari pada WFO.

Organisasi harus merancang strategi, agar bisa merespon krisis dengan tepat. Dari hasil penelitian organisasi maupun perusahaan yang menghadapi krisis yang sama, tetap memiliki respon yang berbeda dalam menangani sebuah krisis (Ham, Hong, \& Cameron, 2012).

Emergency Response Team (ERT) memiliki tujuan untuk menentukan tanggapan yang diberikan oleh organisasi saat terjadi sebuah krisis. Hasil analisis menunjukkan jika Group Head Corporate Communication memilih tindakan pencegahan krisis (prevention) yaitu tindakan yang dilakukan untuk mengurangi dampak negatif dari peristiwa krisis. Sama halnya dengan hasil penelitian (Hasan, S. 2015) yang mengartikan implementasi sebagai intervensi krisis (mencegah kerugian yang lebih besar), melalui perencanaan dan membenarkan tindakannya. Hasil analisis menunjukkan sebagai upaya mencegah krisis akibat pandemic virus Covid-19, Group Head Corporate Communication, Emergency Response Team (ERT) PT. XL Axiata Tbk melakukan beberapa tindakan sesuai dengan permasalahan yang terjadi. Beberapa tindakan yang dilakukan yaitu bekerja sama dengan gugus tugas Covid-19 tingkat nasional dan daerah, penyebaran rilis melalui website, berkomunikasi dengan pemerintahan dalam hal ini kementerian terkait, pemerintah daerah, para pemangku kepentingan, serta memanfaatkan media tradisional dan digital secara massif.

\section{SIMPULAN}

Berdasarkan analisis terhadap temuan penelitian yang dijabarkan di bagian sebelumnya, dapat disimpulkan bahwa krisis di perusahaan atau organisasi dipahami dan dianalisis sesuai dengan kondisi serta konteks yang berlangsung. Apabila merujuk pada teori maka tahapan atau langkah pasti sama tetapi di lapangan sangat berbeda pelaksanaannya. Itu sebabnya krisis tidak dapat digeneralisasi tergantung jenis usaha atau bisnis yang dijalankan. Strategi yang digunakan untuk suatu isu belum tentu efektif untuk menangani isu lainnya, begitu pula sebaliknya. Meskipun demikian, setidaknya ada tahapan baku yang harus dijalankan oleh seorang public relations atau tim yang dibentuk oleh manajemen dalam merespon, mengantisipasi dan menghadapi baik isu atau krisis. Saat ini bisnis PT. XL Axiata Tbk belum terdampak krisis secara langsung, tetapi pihak perusahaan harus merespon masa krisis sehingga tidak mengganggu operasional perusahaan. Dampak operasional yang sangat terasa oleh krisis ini akibat Pembatasan Sosial Berskala Besar (PSBB) karena ruang gerak yang terbatas. Kondisi saat ini oleh banyak negara dikategorikan krisis non alam tetapi krisis wabah kesehatan.

Dengan kondisi ini PT. XL Axiata Tbk. dalam merespon krisis ini membuat tahapan berupa: Pertama, Tahap pembentukan tim, Tim ini sudah ada sebelum Pandemi ini muncul, bahkan Emergency Response Team (ERT) ini sudah dipersiapkan dan dilatih untuk menghadapi segala krisis. ERT ini yang bekerja untuk membuat analisis baik secara mikro dan makro dengan strategi untuk menghadapinya. Kedua, Tahap Analisis, ERT ini membuat apps utk internal karyawan, latihan kerja WFH, monitoring karyawan dan internal komunikasi sampe membuat buku panduan internal disebut buku putih. Ketiga, Tahap Perencanaan, langkah antisipasi untuk menghadapi pandemi perusahaan juga sudah menjalankan Business Continuity Plan. Keempat, Tahap Implementasi, implementasi 
bisnis dari rencana kerja perseroan juga mesti diubah dan menyesuaikan dengan keadaan yang ada, seperti alokasi investasi untuk memenuhi kebutuhan trafik pengguna yang meningkat, termasuk menambah coveragedan kapasitas bandwith.

\section{DAFTAR PUSTAKA}

Akhyar, D. M. \& Pratiwi, A.S. (2019). Media Sosial dan Komunikasi Krisis: Pelajaran dari Industri Telekomunikasi di Indonesia. UltimaComm.Jurnal Ilmu Komunikasi, 11(1), 35-52. https://doi. org/ISSN 2656- 0208

Cangara, H. (2017). Perencanaan dan Strategi Komunikasi. Edisi Revisi. Jakarta: Rajawali Press.

Ham, C. D., Hong, H., \& Cameron, G. T. (2012). Same crisis, different responses: case studies of how multiple competing corporations responded to the same explosion-related crises. International Journal of Business and Social Science, 3(20), 19-31.

Hasan, S. (2015). Strategi Rumah Sakit Dalam Menghadapi Krisis Public Relations Menurut Perspektif Fiqh Muamalat. An-Nisbah: Jurnal Ekonomi Syariah, 2(1). https://doi.org/10.21274/ an.2015.2.1.379-404

Kriyantono, R. (2015). Public Relations, Issue \& Crisis Management; Pendekatan Critical Public Relation, Etnografi Kritis \& Kualitatif.Cetakan-1. Jakarta: Kencana Pranada Media Group.

Kumparan. (2019, Desember 21). Sri Mulyani: Jiwasraya Kasus Besar dan Serius https://kumparan.com/kumparanbisnis/ sri-mulyani-jiwasraya-kasus-besardan-serius-1sULCDR9j84/full

Kustiawati, K. Setiadarma, A. Priliantini, A. (2019). Strategi Public Relations dalam Manajemen Isu Keamanan Pangan di Pizza Hut Indonesia.KOMUNIKA. Jurnal Komunikasi Media dan
Informasi, 8(1), 53-62. https:// DOI: 10.31504/komunika.v8i1.1876

Moleong, J. L. (2010). Metodologi Penelitian Kualitatif. Bandung: PT. Remaja Rosdakarya,

Natawilaga, S. (2018). Peran Etika Dalam Meningkatkan Efektivitas Pelaksanaan Public Relations. WACANA, Jurnal Ilmiah Ilmu Komunikasi, 17(1), 64. https://doi.org/10.32509/wacana. v17i1.492

Nova, Firsan.(2011). Crisis Public Relations. Jakarta: Rajawali Press

Putri, A.W. Sutopo \& Rahmanto, A.N. (2019). Komunikasi Krisis Kementerian Pertanian Pada Kasus Penggerebekan Gudang Beras PT. IBU (Analisis Isi Kualitatif Menggunakan Situational Crisis Communication Theory). Jurnal Studi Komunikasi dan Media, 23 (1), 53-70. DOI10.31445/jskm.2019.1765 ISSN1978-5003

Sa'diyah, H. (2017). Manajemen Krisis Universitas Islam Indonesia (UII) Yogyakarta Dalam Mengatasi Kasus Mapala UNISI. Jurnal Ilmu Komunikasi AKRAB, 2(1), 134-147. Retrieved from http://ojs.akrb.net/index.php/akrab/ article/view/39/16.

Safitri. L. N., \& Aslati, I. K. (2019). Manajemen Krisis Public Relations PT. Indah Kiat Pulp and Paper Tbk. (IKKP) Perawang Terhadap Berkembangnya Isu Pencemaran Lingkungan. JRMDK, Jurnal Ilmu Komunikasi, 1 (1), 29-36.

Suryani, I., \& Sagiyanto, A. (2018). Strategi Manajemen Krisis Public Relations PT Blue Bird Group. Communication, 9(1), 103.https://doi.org/10.36080/comm. v9i1.624.

Suara.com. (2020, April, 6).Giliran Wuling Tutup Pabrik Selama 2 Pekan Karena Covid-19https://www.suara.com/ otomotif/2020/04/06/161136/giliranwuling-tutup-pabrik-selama-2-pekan- 
karena-covid-19.

Sugiyono. (2014). Memahami Penelitian Kualitatif. Bandung: CV Alfabeta.

Suryani, I. \& Sagiyanto, A. (2018).Strategi Manajemen Krisis Public Relations PT Blue Bird Group. Jurnal Communication, 9(1), 102-113. DOI 10.36080/comm.v9i1.624

Wahyuningsih,T. (Maret, 2020). Wawancara Pribadi.

Wasesa, S. A., Macnamara, J. (2010). Strategi Public Relations. Edisi Revisi. Jakarta: PT. Gramedia Pustaka Utama.
Yin, R. K. (2017). Case Study Research and Applications: Design and Methods. Sixth Edition. California: Sage Publications.

Yudho, A.S. (Maret, 2020). Wawancara Pribadi. Yulianti, W., \& Boer, R. F. (2020). Manajemen krisis public relations dalam menangani penolakan imunisasi measles rubella. PRofesi Humas Jurnal Ilmiah Ilmu Hubungan Masyarakat, 4(2), 290. https://doi.org/10.24198/prh. v4i2.23700 